\title{
1. Toward a comprehensive EU-China investment agreement
}

\section{Julien Chaisse}

\section{AN INTRODUCTION}

On 20 February 2012, the European Union (EU) and the People's Republic of China (PRC) decided to launch negotiations on a bilateral treaty addressing the promotion and protection of investment between the two parties. This book anticipates the forthcoming negotiations and examines the legal positions from which the parties will begin their negotiations. In so doing, the book provides stakeholders, such as policy makers, academics and the general public, with a roadmap to the issues raised in the forthcoming negotiations. The negotiation of a bilateral investment treaty (BIT) between the PRC and the EU is likely to be a watershed event in global investment treaty practice. Because of the size and importance of the PRC-EU bilateral investment relationship, and because of the leading role both parties have played in the global spread of BITs, the issues raised, and lessons drawn from the PRC-EU case will have ramifications well beyond China and Europe.

States actively seek to attract foreign investment into their economies because high levels of foreign investment have long been associated with increased economic growth and prosperity. ${ }^{1}$ To put matters into global context, the United Nations (UN) estimates that in 2017 global inflows of foreign direct investment (FDI) amounted to 1.35 trillion USD. ${ }^{2}$ That figure represents capital moving from investors based in one state into investments located in another. In terms of stock, investors based in the EU invested approximately 118.1 billion Euros into investments in the PRC, while investors based in the PRC invested approximately 26.3

1 See J. Sachs, The End of Poverty: How We Can Make It Happen in Our Lifetime (London 2005).

2 See UNCTAD (2017) World Investment Report (New York and Geneva: United Nations). 
billion Euros into investments in the EU. ${ }^{3}$ On the European side, investment from the PRC, while still relatively small in absolute terms (by the end of 2017 China was still not among the top ten investors in the EU-27), represents the fastest growing source of foreign investment into the EU. ${ }^{4}$ On the Chinese side, investment from the EU is only surpassed in amount by investment from the United States (US). For each party, therefore, it is a bilateral relationship of the highest order of importance.

Investors, however, are free to invest where they choose and without legal instruments and mechanisms to protect investments abroad, investors may be reluctant to invest their resources in a foreign state. As a consequence of concerns with respect to differences in legal systems and differences in levels of legal infrastructure, over the past 25 years in particular, states have concluded more than 3,000 BITs to regulate the treatment of foreign investors and investments and to provide a mechanism for the resolution of disputes between foreign investors and host states. The result of this widespread practice by states, entering into thousands of treaties addressing similar subject matter but only in a bilateral manner, is what the UN has labelled a global 'noodle bowl' of BITs and investment-related treaties. ${ }^{5}$ By entering into a myriad of bilateral treaties, often similarly phrased but each a distinct treaty, states have developed a fragmented patchwork in an important area of international economic law. And this fragmentation has grown over time with a continuously increasing number of treaties, actors and fora addressing international investment issues. ${ }^{6}$

In the context of this global fragmentation, a BIT between the PRC and the EU (which negotiators have for now called 'Comprehensive Agreement on Investment') would be a seminal event in global investment treaty practice. A BIT between the PRC and the EU will cover the investment activity of two billion people, easily making it one of the most

3 See Eurostat, 2017 [available at http://ec.europa.eu/eurostat/web/main accessed May 7, 2018].

4 See Frank Bickenbach and others, The EU-China Bilateral Investment Agreement in Negotiation: Motivation, Conflicts and Perspectives, (Kiel Policy Brief, No. 95, 2015) 1, <https://www.ifw-kiel.de/wirtschaftspolitik/zentrum-wirtschafts politik/kiel-policy-brief/kpb-2015/kiel-policy-brief-95> accessed May 7, 2018.

5 See Julien Chaisse and Christian Bellak, 'Navigating the Expanding Universe of Investment Treaties - Creation and Use of Critical Index' (2015) 18(1) Journal of International Economic Law 79-115; Julien Chaisse, 'The Shifting Tectonics of International Investment Law - Structure and Dynamics of Rules and Arbitration on Foreign Investment in the Asia-Pacific Region' (2015) 47(3) George Washington International Law Review 563-638.

6 See K. Sauvant 'New Sources of FDI: The BRICS - Outward FDI from Brazil, Russia, India and China' (2005) 6(5) Journal of World Investment and Trade 639. 
influential international investment treaties in the world. The aim of the China-EU CAI is to substitute the present legal assemblage, which consists of 26 different bilateral treaties that the member states of the EU agreed, three decades ago with China. The two parties believe strongly that the new treaty would affect international investment flow by supplying legal security for existing investment in addition to opening a new market for foreign investors.

China has taken a step forward in its most recent international investment agreements (IIAs) negotiated with countries from the Americas and Asia, in a bid to recalibrate the existing set of investment rules in order to pursue a better balance between foreign investors' rights and the ability of host states to regulate FDI in the public interest, using the China-EU IIA as a perfect pivot. As a result, it has gained a lot of grounds in the EU, in light of its trade agreement to be finalised with Canada.

In addition, the EU-China investment agreement will help immensely in building a coherent global investment era, which will aid in improving the status of existing investment treaties on the ground of an EU-wide IIA with China, by replacing the investment treaties already in existence. If the investment treaties are not replaced, it would result in the complexity of the total system which could affect foreign investors who may decide to sue based on the old treaties that are favourable to them. ${ }^{7}$ The termination approach becomes the alternative for EU and China and other countries like South Africa or Indonesia who also terminated their IIA instead of renegotiating their terms of the agreement. A more coherent global investment governance will emerge if more countries adopt the EU's 'replacement approach' which is geared toward regionalisation of investment rule-making.

Furthermore, China has also been negotiating with the US with regard to an investment treaty with similar features to that of the EU-Chinese agreement. Also, a comprehensive investment charter may be established in the TTIP between the US and Europe. The legal framework being developed from this tripartite relationship will most likely be more stable compared to the treaty practised in the past 50 years and is likely to provide a blueprint for IIAs to be emulated by other countries. The investment negotiations between the EU, the US, and China should include a process of global investment dialogue for it to be all-inclusive.

The need for the EU and China to seek an 'ambitious and comprehensive' agreement on investment is based on series of tactical consideration and motivation. There is the likelihood that an EU-China agreement will

7 See W. Shan 'EU Enlargement and the Legal Framework of EU-China Investment Relations' (2005) 6(2) Journal of World Trade and Investment 237. 
strengthen the EU-China comprehensive strategic partnership, better regulate Chinese investment flooding the EU, provide a level playing field for both investors, improve on the investment roles of the Asia continent, and increase EU and China competitiveness in the global economy. The above reasons are inexhaustive but vividly float on the negotiation table. The EU and China are expected to make frantic efforts to strike a deal that would reflect the relationship between EU and China and pave the way for a high-level free trade agreement (FTA) by meeting their domestic demands.

Concluding the EU-China CAI will require coordination and agreement among the position of 28 states of differing legal, cultural, political and economic traditions. In the context of global investment treaty-making practice and the race in which all countries are engaged to attract FDI, the conclusions reached by the parties will have significant influence beyond China and the EU.

Against this background, this introductory chapter examines the drivers and issues of China-EU investment relationships, the potential innovation in rule-making in the Comprehensive Agreement on Investment (CAI), and the possible reform of ISDS in the context of China-EU investment treaty.

\section{DRIVERS AND ISSUES OF CHINA-EU INVESTMENT RELATIONSHIPS}

In order to explain the dynamics of China-EU negotiations, Part I presents the political, legal and economics drivers and issues of China-EU investment negotiations. The CAI will surpass the impact of an agreement that is narrowed down to bilateral cooperation. The future of the China-EU relation with regard to BIT will either strengthen their cooperation and improve their economic relationship that is mutually profitable to them or leading to a rivalry between them on who to have the biggest portion of the global market depending on other PTAs with a third-party state.

For the EU, the negotiation of a BIT with the PRC comes at a singular moment of constitutional development. As of December 2009, and the entry into force of the Treaty on the Functioning of the European Union, exclusive competence for the negotiation and conclusion of BITs has been transferred from the EU member states to the EU itself. ${ }^{8}$ This means

8 See S. Woolcock, European Union Economic Diplomacy: the Role of the EU in External Economic Relations (Farnham: Ashgate, 2012). See also Julien Chaisse, 'Promises and Pitfalls of the European Union Policy on Foreign Investment - How Will the New EU Competence on FDI Affect the Emerging Global Regime' (2012) 15(1) Journal of International Economic Law 51-84 and J. Kleinheisterkamp, (2013) 
that the negotiation of a PRC-EU BIT will entail the replacement of the numerous existing BITs currently in force between the PRC and individual EU member states. The consequences of this (r)evolution in EU investment treaty-making practice are only gradually being revealed in official documents from the EU. ${ }^{9}$ What is clear, however, is that because the negotiations with the PRC come at such an early moment in the EU's exercise of its new competence, the experience of the negotiations and the terms of a concluded treaty will have a substantial impact on the way in which the EU coordinates its investment treaty policy and negotiates investment treaties on behalf of its member states well into the next decade.

The PRC stands in a particular position - it has been for the last decade the primary developing country recipient of foreign direct investment. As a capital exporter developing country, China also ranks amongst the world highest third. ${ }^{10}$ From this dual perspective, contemporary China's interests lie in providing substantive protection for its investors abroad as well as opening new investment opportunities. At the same time, it undertakes to consolidate international obligations and internal reforms that are conducive to opening up the domestic market and creating a stable business environment. One could identify three generations of PRC investment agreements as stylised facts of the international investment 'system'. ${ }^{11}$ A 'first generation' (1980s and 1990s) set of BITs focuses on the protection of foreign investors, albeit maintaining some important

'International Investment Law and Its Intersection with EU Law and Policy' in N.J. Calamita, et al (eds), The Future of ICSID and the Place of Investment Treaties in International Law (London: British Institute of International and Comparative Law) 364.

9 See N.J. Calamita, 'The Making of Europe's International Investment Policy - Uncertain First Steps' (2012) 39(3) Legal Issues of Economic Integration 301.

10 The PRC's outward direct investment has increased drastically from USD 1.9 billion in 2004 to USD 80.4 billion in 2017 as contained in the official statistics issued by the State Administration of Foreign Exchange (SAFE), which is an administrative agency of the People's Republic of China. See Duncan Freeman, 'China's Outward Direct Investment in The EU: Challenges of Rapid Change, In EU-China Observer', Exchanging Ideas on EU-China Relations: An Interdisciplinary Approach, \# 3.15, (2015) 5-10, 5, <https://issuu.com/collegeofeurope/docs/eu-china_observer315> accessed May 7, 2018.

11 See A. Berger (2008) 'China and the Global Governance of Foreign Direct Investment - The Emerging Liberal Bilateral Investment Treaty Approach' (Bonn: Working Paper Deutsches Institut für Entwicklungspolitik) 42. See also S.W. Schill 'Tearing Down the Great Wall: The New Generation Investment Treaties of the People's Republic of China' (2007) 73(15) Cardozo Journal of International \& Comparative Law 76 and N. Gallagher and W. Shan Chinese Investment Treaties: Policies and Practice (Oxford: Oxford University Press, 2009) p. 592. 
reservations on some key guarantees toward foreign investment, such as national treatment, measures against unlawful expropriation, and access to international arbitration. A 'second generation' (2000-10) of international agreements - embodied by a majority of BITs as well as investment disciplines adopted in some FTAs - provides broader and more substantive obligations in regard to the treatment of foreign investment. Post-establishment national treatment - albeit with sectoral reservations in some cases - and no substantial restrictions on the ability of foreign investors to challenge host-country measures in international arbitration are standard in this category. Recent model BITs and investment chapters of the growing number of FTAs represent a nascent 'third generation' of investment agreements. These agreements maintain the high standards on the protection of investments recognised in second-generation agreements while they seek to open new investment opportunities in foreign markets through national treatment in regard to entry rights - subject to sectoral exclusions in the forms of positive and negative. Interestingly, China's 'third generation' investment agreements aim also at ensuring that the rights for foreign investors do not override domestic regulatory powers on other key policy areas. China's interest in negotiating a BIT with the EU is twofold, as a leading capital-importing economy and the emerging leader in capital exports. Coping with the quickly evolving nature of the international investment law system and reaping the benefits of international agreements, while ensuring domestic regulatory capacity with a view to sustain its growing economy, will be a crucial challenge in the forthcoming negotiations.

In Chapter 2, Duncan Freeman examines the Political Driver of the EU-China CAI. The EU-China treaty is being negotiated at a time of uncertainty in global economics and politics and also in the EU-China relationship. A key policy aim of the CAI is to increase investment flows between the EU and China, but it has the potential to reach beyond this basic goal in its significance. One aspect of wider importance for the CAI may be that the agreement itself could encompass innovations in the governance of FDI when compared to those contained in similar existing bilateral and regional agreements. In this sense, the CAI may be able to stake a claim to global leadership in the governance of FDI. But the economic and political context surrounding the agreement may determine how the possibility for leadership in the area of FDI governance will be realised.

In Chapter 3, Eleftheria Neframi extends the analysis by looking at the legal driver of the EU-China CAI. The European Court of Justice opinion 2/15 addresses the question of the external competence of the EU to conclude a free trade agreement with Singapore (EUSFTA). The nature 
of the EU's competence determines the conclusion of an EU-only agreement, or a mixed agreement, jointly by the Union and its member states. The Court of Justice of the European Union held that the EU competence to conclude the EUSFTA is not exclusive, as long as provisions concerning non-direct investments and dispute settlement fall under the shared competence of the Union and its member states. The Court of Justice made valuable contributions to the interpretation of the scope of the Union's competence in the field of common commercial policy, comprising sustainable development provisions, as well as to the interpretation of implied external competences, and clarified the status of non-substantive provisions. However, uncertainty remains as far as the meaning and the impact of a shared competence are concerned.

In Chapter 4, Pascal Kerneis explores the economic driver of the EU-China CAI. He observes that market access barriers remain important in China in most of the listed sectors. And it has not been really possible to test the real political willingness of China to open further through bilateral or plurilateral trade and investment negotiations: China had expressed an interest in entering into negotiations in the Trade in Services Agreement (TiSA). The TiSA negotiations started in 2013 but are currently stalled due to the uncertainty created by the election of Donald Trump as President of the United States. China was also entering into the final phase of the negotiations of a bilateral investment agreement with the US, but they also have been stalled and it is not clear whether the new US administration will be willing to resume them both. As a result, the negotiations of the EU-China Comprehensive Investment Agreement are the real test for the Chinese authorities. The business community would aim at the removal of all equity caps, with negotiated exceptions. Business will also look at getting more commitments in professional services, which include lawyers, auditors and accountants, architects and engineers, etc., in telecommunication services, in postal and express services, and in the various financial services sectors (banking, asset managements, insurance). For instance, it is expected that the negotiators will try to remove or reduce these following existing equity caps and joint venture requirements: so far, foreign stakes are limited to 50 per cent in value-added telecom services (excepting e-commerce); 49 per cent in basic telecom enterprises; 50 per cent in life insurance firms and 49 per cent in security investment fund management companies.

In Chapter 5, Fernando Dias Simões discusses the role of sustainability impact assessment in the EU-China BIT negotiations. Impact assessment studies are a well-established instrument to inform trade and investment negotiators and steer their decision-making processes. The European Union's trade Sustainability Impact Assessment programme offers an 
opportunity for stakeholders in both the European Union and its partner countries to share their views with policymakers. This chapter examines the level of stakeholder involvement in the Sustainable Impact Assessment study currently underway in support of the negotiations for a Bilateral Investment Treaty between the EU and China. It argues that several factors seemingly reduce the opportunity for some stakeholders to share their views with negotiators, raising doubts about their potential contribution to the policymaking process. Public consultation mechanisms have been criticised by some sectors of European Civil Society. The uniqueness of China's civil society presents further challenges since the degree of stakeholder involvement and independence from government cannot be compared to the European context.

\section{CHINA-EU: TOWARDS INNOVATION IN RULE-MAKING?}

Part II explores the potential innovations in rule-making in the CAI. Concluding a BIT between the PRC and the EU will require coordination and agreement among the positions of 28 states of differing legal, cultural, political and economic traditions. Only by examining the prior treatymaking practice of the PRC and EU member states, putting this practice into the specific context of PRC-EU investment relations, and considering global and regional trends with respect to the litigation of investor-state claims, will negotiators be able to identify the key issues between the parties. In certain areas, because of shared interest or historically similar treaty-making practice, agreement on key issues is likely to exist at the outset of negotiations. In other areas, differences in negotiating objectives and/or treaty-making approach may make agreement on text difficult. This research will provide a roadmap identifying these areas of likely agreement and disagreement and suggest possible solutions. The research plan anticipates a four-stage approach employing complementary methods of analysis.

In Chapter 6, Jiaxiang $\mathrm{Hu}$ focuses on the issue of national treatment and free trade zones (FTZs). Unlike all the previous Special Economic Zones which, more or less, received some incentive policies and tax reductions from the central government, the Free Trade Pilot Zones have not been offered any preferential treatment in an economic sense. Instead, they are encouraged to experiment with new innovative measures in market access and administrative regulation. With the piloting reforms in the following years, these FTZs shall expedite the functional transformation of government through streamlining the administrative power, expand 
the opening up of service sectors by releasing the limitations on market access, promote the reform of administrative regulation on foreign investment, develop the multinational corporation headquarter economy with more sophisticated facilities and try experiment with new trade forms. As such, experience hence gained shall serve nationwide with new ideas and approaches in the next round of economic reforms.

In Chapter 7, Catharine Titi looks at the ways and means of refining the expropriation clause, in particular by including a proportionality test. The role of proportionality in international investment law is largely conditioned on whether proportionality is considered a general principle of law or an element of material law, applicable only when explicitly or implicitly incorporated into a given set of rules. The chapter explores proportionality in relation to the expropriation standard in light of new investment treaty formulations and with a particular reference to the context of the EU-China investment negotiations. It discusses the dual approach to proportionality, as a general principle of law and as an element of substantive law. To better understand the function of proportionality, it establishes a comparative context, detailing the case law of the WTO's adjudicative bodies, the CJEU and the ECtHR. It then turns to proportionality analysis in investment treaty arbitration, its explicit incorporation in IIAs, it addresses some related criticisms and argues that proportionality can be a useful tool for balancing competing interests.

In Chapter 8, Jorun Baumgartner assesses states' policy options to limit the practice of treaty shopping in new IIAs, focusing on the definitions of investor and investment. To this end, after defining the relevant scenarios of treaty shopping, exploring the reasons for its occurrence (section 2) and explaining the relevance of refined investor and investment definitions in a prospective China-EU BIT (section 3), this contribution will address the legal issues arising with respect to the investor and investment definitions, discuss relevant arbitral practice and examine EU and Chinese IIA practice in this regard (section 4). It will show that careful treaty drafting, containing more clarity as to the key definitions, can go a long way toward ensuring that only those investors and investments contemplated by the negotiating parties will benefit from treaty protection.

In Chapter 9, Federico Lupo-Pasini explores the emerging regulatory issues for financial services in the new generation of FTAs. Financial services are key components of modern FTAs. More than any other sectors, finance has undergone a process of regulatory and structural change over the last ten years. New methods of financial intermediation have emerged, and new regulatory instruments have been adopted to address the regulatory loopholes evidenced by the recent global financial crises. The regulatory framework applicable to trade in financial services 
in FTAs has largely remained the same. However, the increased use of investment chapters in FTAs is changing the way financial services will be treated soon. Investment law brings a completely new dimension to the regulation of financial services, as its discipline is much more likely to impact on the way finance is regulated in domestic law. In this chapter three issues that are particularly revealing of this trend are examined: the restructuring of sovereign debt securities; the resolution of a cross-border financial institution; and the use of international courts to challenge a domestic supervisory decision.

In Chapter 10, Donald J. Lewis reviews the OBOR in the context of China-EU FDI. China's OBOR Initiative is a bold, visionary, highly elaborated blueprint, with many inter-connected moving parts, that, on both theoretical policy and practical business levels, offers perhaps humankind's main chance for 21 st century prosperity on a global scale - and the achievement of the heretofore unattainable prospect of peaceful Eurasian and African economic integration. To accomplish such monumental geopolitical transformations will require not only China's own gargantuan efforts, but also those of the other great powers, including Russia, the EU and the US. Wisely, China has generously formulated OBOR in such a way that it embraces inclusiveness. If cooperation can replace selfish rivalry, we may perhaps be on the cusp of a new, promising and affirming human epoch - what the Chinese are calling a 'community of common destiny'.

In Chapter 11, Nguyen Binh Duong looks at the EU-Vietnam FTA investment chapter which can be seen as a template for the EU-China CAI. On 2 December 2015, the negotiation of the EU-Vietnam Free Trade Agreement was officially completed. This is a new generation FTA with a very wide scope. One of the chapters considered to have direct impacts on Vietnam's law is investment chapter. Chapter 11 aims to analyse investment related provisions of EVFTA and to indicate some incompatibilities between EVFTA investment provisions and Vietnamese law. Basing on these analyses, this chapter proposes some recommendations for Vietnam to reform the legal system to improve the investment environment, to facilitate sustainable development and to benefit both domestic and foreign investors.

In Chapter 12, Chien-Huei $\mathrm{Wu}$ reflects the consequences of the CAI for the Taiwan-EU relationships. In its latest trade strategy document, released in 2015, Trade for All, the EU declared that: '[B]uilding on the investment provisions under negotiation with China, the EU will explore launching negotiations on investment with Hong Kong and Taiwan.' Such a proposal has been welcomed by Taiwan, but the road toward an EU-Taiwan bilateral investment treatment (BIT) is destined to be long 
and tortuous. In view of these uncertainties, this chapter aims to probe the possible course of the EU-Taiwan BIT negotiations and outline a roadmap. This chapter first portrays current political and economic relations between the EU and Taiwan and then explores the possible form of the envisaged EU-Taiwan BIT by examining such critical issues as the contracting parties, the design of investor-State dispute settlement, the investment court proposal by the EU and the sequence in which the EU might conclude BITs with China and Taiwan.

\section{FROM INVESTOR-STATE ARBITRATION TO A PERMANENT INVESTMENT COURT?}

Part III focuses on the management of investment disputes in the future CAI. There has been criticism on the EU-China investment treaty due to the inclusion of controversial investor-state dispute settlement (ISDS) clauses which permit foreign investor to institute an action against host states before international tribunals without having recourse to their national legal system. The principle of fair hearing and equitable treatment have been hidden by the ISDS clauses which have led to its criticism in recent time and this has resulted in the negative influence on host governments' ability to regulate in public interest. The inclusion of investment dispute in the TTIP which is a treaty entered between two industrialised countries with highly developed imperial legal system may not be needed since the EU-China treaty represents a case that is different. Although, the status quo is unsatisfactory, since most of the IIAs negotiations between China and practically all, except one EU member state, which contains unrestrained ISDS provisions and far-reaching substantive provisions, the EU-China IIA, would not create new sets of investment rules in comparison with TTIP. As a result, Chinese investors already have recourse to international arbitration/mediation to enforce their rights against European Governments. A typical example of this is a claim filed by the Chinese insurer Ping An, against the Belgian government in the awakening of the global financial crisis in 2012.

In Chapter 13, Joanna Jemielniak analyses the EU Investment Court System as a hybrid mechanism. The concept of establishing a permanent adjudicatory body for investor-state disputes has become very close to political fulfilment. The European Commission has endorsed introduction of a permanent, court-like mechanism for investment disputes in several FTAs. A two-tier Investment Court System (ICS) has been accepted in the EU's FTA with Vietnam (EVFTA) and in the Comprehensive Economic and Trade Agreement (CETA) between Canada and the EU. This widely 
publicised EU ICS project has been presented as a court, to be further promoted in forthcoming EU FTA negotiations, and multilateralised in the future. It has also been introduced to the public in opposition to the existing ISDS regime and as an original response to its shortcomings. This chapter examines to what extent such a characterisation of the ICS is justified. For this purpose, historical context of investor-state dispute resolution is explored. In particular, former proposals of establishment of a permanent adjudicatory body in this area are examined. Against this background, public discourse on ICS is analysed in order to present the goals of the project and its aimed directions of development.

In Chapter 14, Chi-Chung Kao reflects on the inclusion of investment court system into the EU-China BIT. The ICS is intended to improve ISDS with its procedural innovations. But the rules concerning the unilateral appointment of arbitrators by the states are problematic. The presumption that an investor-appointed arbitrator is biased in favour of the appointing investor is proven by empirical statistics as untrue; the allegation that party-appointed commercial arbitrators are not capable of handling claims involving public interest is equally unfounded. In addition, actual cases have demonstrated that the integrity of the arbitral proceedings can be effectively upheld by the challenge mechanism, under which a potentially partial or biased arbitrator can be removed. The deprivation of the investor's right to appoint an arbitrator is a disproportionate measure in this regard. Finally, investors might lose their confidence in arbitration if arbitrators are pre-installed by the states. Investors might feel unwilling to have recourse to arbitration and turn to their home state for intervention instead. This could cause a setback in the depoliticisation of ISDS. There is nothing fundamentally wrong with the conventional approach of parties appointing arbitrators. The ICS's rules in this regard jeopardise, rather than improve ISDS. If the EU-China BIT does incorporate the ICS, it would be better if the ICS is modified so the disputing parties retain their right to appoint arbitrators.

In Chapter 15, Matthew Hodgson and Vee Vian Thien critically examine the appellate option. In arbitration, the finality of the award is typically prioritised over correctness, so that the parties enjoy the advantages of cost effectiveness and expedience. However, it is arguable that the balance should be re-assessed in relation to investor-state disputes as opposed to purely commercial arbitrations, as the former involve acts of government and questions of public interest. This chapter provides an overview of the perceived shortcomings of the present system, a summary of the EU's proposed reforms and evaluates how far the introduction of an appeal mechanism would address concerns over ISDS such as predictability and consistency of awards. 
This work is the result of considerable collective effort, which started with the Asia FDI Forum III held in Hong Kong on May 11-12, 2017, an event jointly organized by the CUHK Law Faculty, Columbia University Centre for Sustainable Investment (CCSI) and the World Economic Forum (WEF), which has been generously supported by the CUHK Faculty of Law and the WEF. The work has benefited immensely from contributions from many sources, both at the institutional as well as at the individual level. I am delighted at the final result and would sincerely like to express our gratitude to all who have contributed to this project in one way or the other. Thanks must also be extended to our research assistants Ms. Rachel Xu Qian and Mr. Keith Ji. I also want to express sincere thanks to the many members of the CUHK Law Faculty who have played an important role in bringing this volume to fruition, namely Christopher Gane (Dean of CUHK Law), Denis Edwards, Flavia Marisi, Lutz-Christian Wolff, Chao Xi, and Yan Xu. I am also sincerely thankful to Edward Elgar for their efficient preparation of the final text for publication. 